\title{
Pulp canal obliteration after traumatic injuries in permanent teeth - scientific fact or fiction?
}

\section{Juliana Vilela BASTOS(a) Maria Ilma de Souza CÔRTES(b)}

(a) Universidade Federal de Minas Gerais UFMG, School of Dentistry, Department of Restorative Dentistry, Belo Horizonte, MG, Brazil.

(b)Pontifícia Universidade Católica de Minas Gerais - PUC-MG, Department of Dentistry, Belo Horizonte, MG, Brazil.

Declaration of Interests: The authors certify that they have no commercial or associative interest that represents a conflict of interest in connection with the manuscript.

Corresponding Author: Maria Ilma de Souza Côrtes E-mail:cortesmi@globo.com

Submitted: May 06, 2018

Accepted for publication: May 29, 2018

Last revision: June 07, 2018

\begin{abstract}
Pulp canal obliteration (PCO) is a frequent finding associated with pulpal revascularization after luxation injuries of young permanent teeth. The underlying mechanisms of PCO are still unclear, and no experimental scientific evidence is available, except the results of a single histopathological study. The lack of sound knowledge concerning this process gives rise to controversies, including the most suitable denomination. More than a mere semantic question, the denomination is an important issue, because it reflects the nature of this process, and directly impacts the treatment plan decision. The hypothesis that accelerated dentin deposition is related to the loss of neural control over odontoblastic secretory activity is well accepted, but demands further supportive studies. PCO is seen radiographically as a rapid narrowing of pulp canal space, whereas common clinical features are yellow crown discoloration and a lower or non-response to sensibility tests. Late development of pulp necrosis and periapical disease are rare complications after PCO, rendering prophylactic endodontic intervention useless. Indeed, yellowish or gray crown discoloration may pose a challenge to clinicians, and may demand endodontic intervention to help restore aesthetics. This literature review was conducted to discuss currently available information concerning PCO after traumatic dental injuries (TDI), and was gathered according to three topics: I) physiopathology of PCO after TDI; II) frequency and predictors of pulpal healing induced by PCO; and III) clinical findings related to PCO. Review articles, original studies and case reports were included aiming to support clinical decisions during the follow-up of teeth with PCO, and highlight future research strategies.
\end{abstract}

Keywords: Tooth Avulsion; Dental Pulp; Wound Healing; Regeneration.

\section{Introduction}

Dentin synthesis and apposition along dental pulp cavity walls occur throughout the life of a vital tooth. This process is characterized by stages that occur at different rates, and results in distinct types of dentin, albeit attributed to the same specialized cell, the odontoblast. During tooth development primary dentin is produced at an accelerated rate $(6.4 \mu \mathrm{m} /$ per day). When root formation is complete after the closure of the apical 
foramen, the rate of dentin apposition diminishes drastically $(0.8 \mu \mathrm{m} /$ per day) and occurs along all pulp cavity walls, but not uniformly throughout the coronal pulp. This process is called secondary dentinogenesis and represents a normal physiological aging outcome and a response to normal tooth wear. Tertiary dentin is region-specific and is deposited in response to injury; it can be divided into reactionary and reparative dentin. ${ }^{1}$ However, this process can be accelerated in teeth affected by traumatic injuries (TI $)^{2,3,4,5}$ or involved in autotransplantation, ${ }^{7,8,9,10}$ orthodontic therapy, ${ }^{11,12}$ jaw fractures ${ }^{13}$ and orthognathic surgery, ${ }^{14,15}$ leading to rapid obliteration of the pulpal cavity.

There are a myriad of terms and expressions used in dental literature to designate this condition. The American Association of Endodontists defines calcific metamorphosis as "...A pulpal response to trauma characterized by rapid deposition of hard tissue within the canal space." 16 This denomination was adopted by several authors, including Patterson and Mitchell, ${ }^{17}$ who also mentioned the expression pulp canal obliteration in their paper; Holcomb and Gregory Junior, ${ }^{18}$ Smith, ${ }^{19}$ Schlinder and Gullickson, ${ }^{20}$ West,${ }^{21}$ Amir et al.,r2 Gopkrisna et al.,r ${ }^{23}$ Malhotra and Mala, ${ }^{24}$ and Siddiqui and Mohamed. ${ }^{5}$ The term obliteration was used by Andreasen, ${ }^{25}$ Stålhane and Hedegård, ${ }^{26}$ and by Jacobsen and Kerekes, ${ }^{27}$ who referred to the term as a pulp cavity calcifying process. It has been called reduced pulpal lumen, ${ }^{28,29}$ dystrophic calcification, ${ }^{30}$ pulp calcification, ${ }^{31}$ calcific pulp obliteration, ${ }^{32}$ and pulp canal sclerosis. ${ }^{33}$ However, after the studies conducted by Andreasen et al., ${ }^{6}$ the denomination Pulp Canal Obliteration (PCO) has become a more appropriate manner of designating this pulpal response to traumatic dental injury (TDI). More than a mere semantic question, the term PCO more precisely reflects the nature of this response. Although dystrophic pulp calcifications may frequently be found within the pulp of obliterated canals, this is a secondary finding. ${ }^{17,28}$ Any denomination that includes the term "calcification" may mislead to making an erroneous association with the replacement of pulpal soft connective tissue by calcific tissue due to pathologic alterations in collagen molecules. ${ }^{34}$ As for the denomination metamorphosis, considering the meaning of the term: "... a marked change in appearance, form and function of a tissue or organ that usually involves a sort of re-activating of genes, which allows cells to change from one type to another...", 35 its use also contributes to the misconception that the pulp undergoes detrimental changes during PCO. On the contrary, it is well accepted that the main mechanism leading to reduced pulpal lumen after TDI is excessive and rapid dentin apposition due to pulpal healing by revascularization, and not a kind of pulpal pathology ${ }^{36}$ Hence, these concepts should be kept apart, because they directly impact the decision to perform endodontic therapy in obliterated canals.

\section{Physiopathology of PCO after TDI}

Accelerated hard tissue formation within the pulp cavity in the first year after trauma is usually diagnosed in imaging exams. A reduction in the size of the coronal pulp chamber is initially observed, and is followed by the gradual narrowing of the entire root canal, not rarely leading to complete obliteration, although a narrow root canal space always persists histologically. ${ }^{17,28}$ Early clinical literature provided the first evidence of the healing nature of PCO after TDI. ${ }^{18,27,37}$ A single histopathological study conducted by Lundberg e Cvek ${ }^{28}$ assessed the pulpal status of permanent teeth with PCO. The pulps of 20 maxillary permanent incisors with reduced pulpal spaces were evaluated. Treatment was performed about 44 months after the injury. Eighteen teeth exhibited narrowing of the entire pulpal lumen, and two teeth demonstrated narrowing in the apical half of the root. The histological results revealed that the pulps varied from being rich in cells with a slight increase in collagen content to being rich in collagen with a marked decrease in the number of cells. No microorganisms were found in any specimen. A moderate inflammatory response was seen in only one pulp.

Andreasen et al. gathered previous information from clinical observations, ${ }^{18,27,37}$ histopathological findings ${ }^{28}$ and experimental results regarding the autonomic control over dentin production, ${ }^{38,39}$ and hypothesized that $\mathrm{PCO}$ was related to revascularization after severe injury to the pulpal neurovascular bundle. Differences in the chronological patterns of neural 
and vascular repair could lead to losing control of sympathetic nerve stimulation over odontoblastic secretory activity, resulting in rapid deposition of dentin and obliteration of the pulpal lumen. Once pulpal revascularization and reinnervation are complete, inhibitory control of odontoblastic secretion can reinitiate, thus ceasing the process and resulting in partial PCO. This regulatory mechanism over dentin synthesis may never be reinstated, leading to complete obliteration. Since obliteration progresses in a corono-apical direction, partial PCO usually affects the pulp chamber and the coronal part of the canal, whereas the radicular part remains visible, albeit markedly narrowed (Figure 1). 6,18,27 There are also clinical reports of partial PCO affecting only the apical third of the root canal (Figure 2). ${ }^{40,41}$ Total PCO is diagnosed when both aspects of the pulp cavity are hardly discernible, or not at all visible (Figure 3).

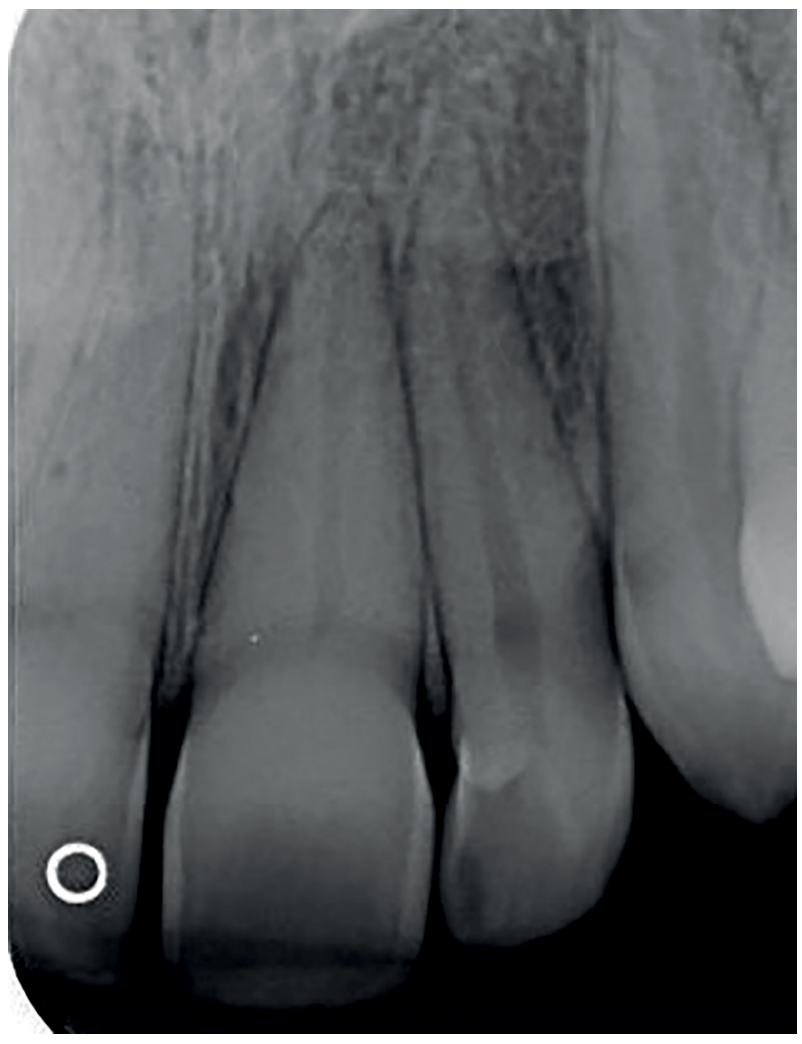

Figure 1. Partial PCO affecting tooth 21 after subluxation. Partial PCO usually affects the pulp chamber and the coronal part of the canal, whereas the radicular part remains visible, albeit markedly narrowed.

\section{Frequency and predictors of pulpal healing with PCO after TDI}

Prevalence of pulp canal obliteration after TDI varies widely in clinical literature, ranging from

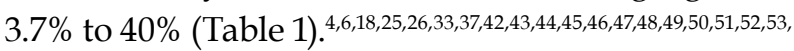
$54,55,56,57,58$ This range can be explained by differences in sample compositions. Development of PCO depends on two main factors: the type of injury and the patient's age at the moment of trauma. PCO seems to be dependent on the presence and extent of the luxation injury, and is more frequent after displacements, as depicted in the clinical studies summarized in Table 1. In this regard, it should be borne in mind that concussion and lateral luxation were added to the WHO clinical classification by Andreasen only in the seventies. ${ }^{59}$ Considering that, these types of luxations were grouped together with other categories in the past, the results in former publications could have been influenced negatively

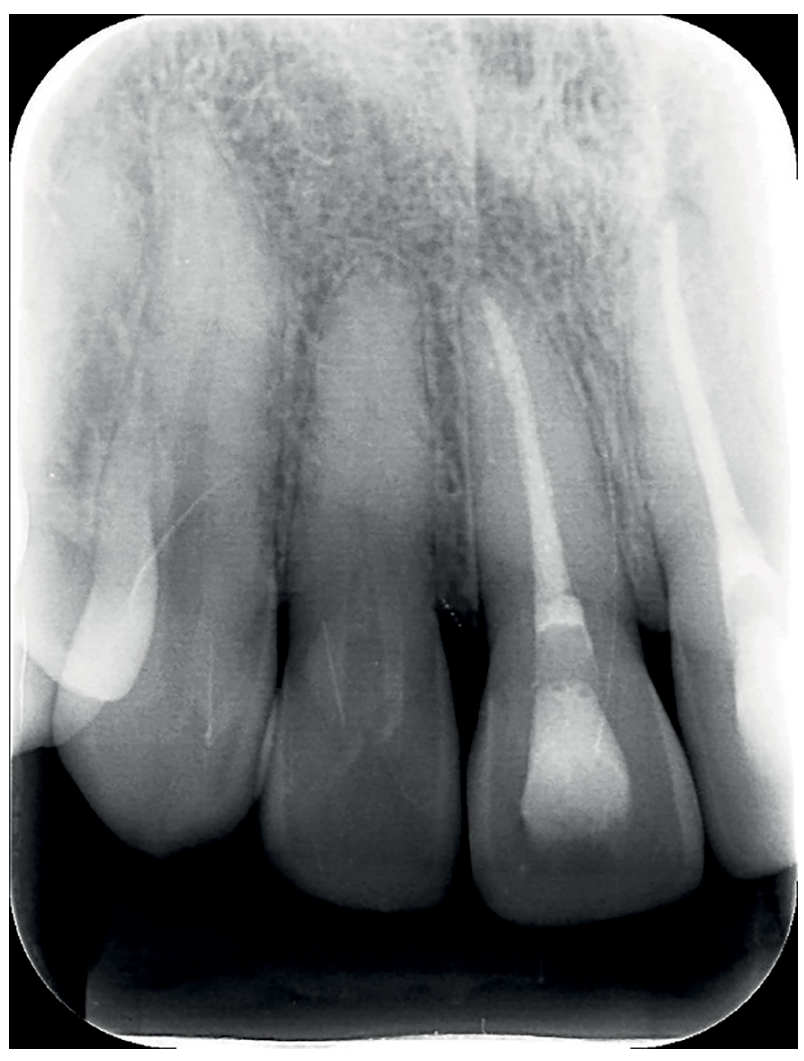

Figure 2. Partial PCO affecting tooth 12 only in the apical third of the root canal. TDI was classified as subluxation. 


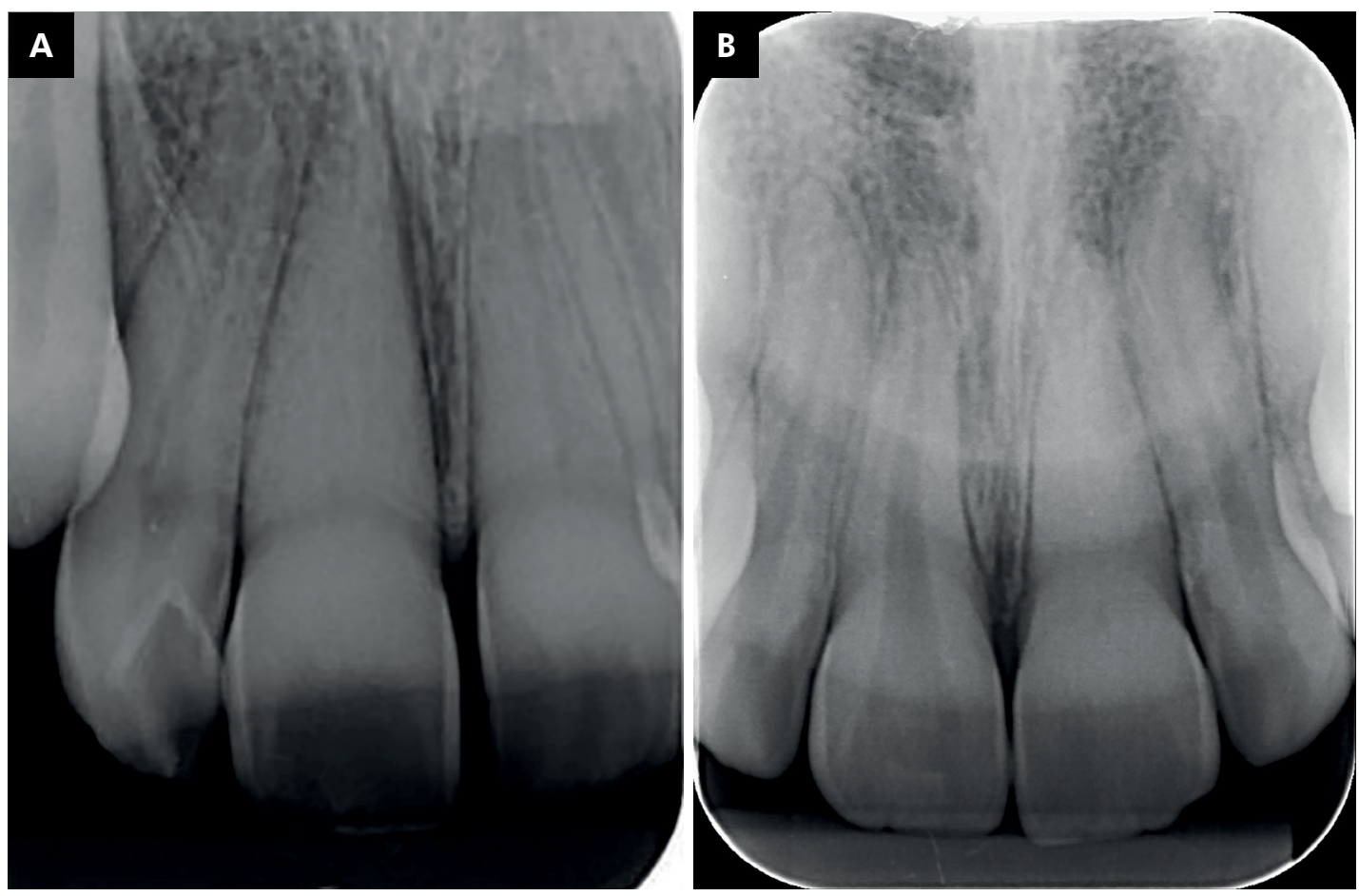

Figure 3. a) Total PCO in tooth 11 after a subluxation. Both aspects of the pulp cavity are hardly discernible; b) Total PCO in tooth 21 after a concussion. Both aspects of the pulp cavity are not at all visible.

or positively, depending on the category in which these conditions were grouped. ${ }^{18,25,26,37}$ Nonetheless, later clinical data were consistent in demonstrating that extrusions $s^{6,43,50}$ and lateral luxations ${ }^{51}$ showed the highest rates of PCO. Interestingly, the splinting of luxated teeth with orthodontic bands, a technique used prior to that of acid-etched wires, was also found to be significantly related to the development of PCO. ${ }^{6}$ This association can be explained by the additional injury that forceful placement of orthodontic bands can cause. In some cases, this type of fixation can lead to displacement of initially nondisplaced traumatized teeth, a theory in agreement with the proposed mechanisms of PCO. The high prevalence of $\mathrm{PCO}$ after root fractures in permanent teeth is noteworthy. The rates of frequency reported in clinical studies ranged from $29.4 \%$ to $95.2 \%, 31$ $, 33,42,44,45,48,49,54,56$ irrespective of the location of the fracture. PCO affecting both fragments of the fracture is the most frequent finding, followed by obliteration of the apical part of the root canal. PCO in the coronal fragment alone was also found, albeit more rarely. ${ }^{33,44,45,54}$ Obliteration of the apical fragment of root fractured teeth was also reported in cases of pulp necrosis. ${ }^{44,45} \mathrm{PCO}$ location in root fractured teeth seems to be associated with the type of healing, since obliteration of both fragments was more common after healing with connective and bone tissue. ${ }^{32,44,45}$ The very frequent occurrence of PCO after root fracture can be attributed to the more extensive communication between the injured pulp and the periodontal tissues, thereby facilitating the reestablishment of the blood supply at the fracture line.

PCO is not only associated with the type of injury, but also with the patient's age at the moment of a trauma that affects mainly teeth with incomplete root development at the time of injury ${ }^{6,43,47,55}$ Considering that $\mathrm{PCO}$ is a phenomenon that depends on both the loss and reestablishment of the neurovascular supply, the larger apical diameter of immature teeth provides a larger interface between vital periodontal tissues out of which new nerves and vessels can grow into traumatized pulp, thus ultimately improving the possibility of pulp revascularization. 
Table 1. Prevalence of PCO after TDI: clinical reports.

\begin{tabular}{|c|c|c|c|c|c|c|}
\hline \multirow[b]{2}{*}{ Author } & \multirow{2}{*}{$\begin{array}{l}\text { Follow-up period - } \\
\text { Mean (range) }\end{array}$} & \multicolumn{3}{|c|}{ Sample features } & \multicolumn{2}{|c|}{ PCO Prevalence N (\%) } \\
\hline & & $\begin{array}{l}\text { Age at trauma - } \\
\text { Mean (range) }\end{array}$ & $\begin{array}{l}\text { Sample size - } \\
\text { patients/teeth }\end{array}$ & $\begin{array}{c}\text { Type of injury (number of } \\
\text { teeth) }\end{array}$ & $\begin{array}{l}\text { Per type of } \\
\text { injury }\end{array}$ & Total \\
\hline Holcomb \& Gregory (1967) ${ }^{18}$ & $4 y$ & 11.2 y $(7-16)$ & $34 / 41$ & - & & $41(3.96)$ \\
\hline \multirow{3}{*}{ Andreasen $(1970)^{25}$} & \multirow{3}{*}{3.4 y $(1-12)$} & \multirow{3}{*}{$0-\geq 20$} & \multirow{3}{*}{ 108/189 } & Subluxations (78) & $20(26)$ & \multirow{3}{*}{$42(22)$} \\
\hline & & & & Intrusions (23) & $1(4)$ & \\
\hline & & & & Extrusions (88) & $21(24)$ & \\
\hline \multirow{3}{*}{ Stålhane \& Hedegård (1975) 26} & \multirow{3}{*}{4.9 y $(1-8)$} & \multirow{3}{*}{$7-15 y$} & \multirow{3}{*}{$2901 / 4926$} & Crown fractures (1463) & $6(0.4)$ & \\
\hline & & & & Subluxations (1018) & $48(4.7)$ & \\
\hline & & & & Luxations (104) & 19(19.5) & \\
\hline Jacobsen \& Zachrison $(1975)^{42}$ & 6 y $(1-\ldots)$ & $10.2(6-21)$ & 51 teeth & Root fractures & & $44(86)$ \\
\hline \multirow{2}{*}{ Rock \& Grundy $(1981)^{37}$} & \multirow{2}{*}{$2-7$ y } & \multirow{2}{*}{8.4 y $(5-21)$} & \multirow{2}{*}{$309 / 517$} & Subluxations (379) & $51(13.5)$ & \multirow{2}{*}{$84(16)$} \\
\hline & & & & Luxations (138) & $33(23.9)$ & \\
\hline \multirow{5}{*}{ Andreasen et al. $(1987)^{6}$} & \multirow{5}{*}{5 y $(0.5-10)$} & & \multirow{5}{*}{$400 / 637$} & Concussions (178) & $9(5.1)$ & \multirow{5}{*}{$96(15)$} \\
\hline & & & & Subluxations (223) & $23(10.3)$ & \\
\hline & & & & Extrusions (53) & $24(45.3)$ & \\
\hline & & & & Lateral luxations (122) & $34(27.9)$ & \\
\hline & & & & Intrusions (61) & $6(9.8)$ & \\
\hline \multirow{5}{*}{ Oikarinen et al. (1987)43 } & \multirow{5}{*}{22 month (6-32) } & \multirow{5}{*}{$17.2(6-64)$} & & Subluxations (48) & $12(25 \%)$ & \\
\hline & & & & Lateral Luxations (42) & $15(36 \%)$ & \\
\hline & & & $76 / 172$ & Extrusions (32) & $13(41 \%)$ & $42(24)$ \\
\hline & & & & Crown fractures + Lux (25) & $3(12 \%)$ & \\
\hline & & & & Avulsion (25) & $2(8 \%)$ & \\
\hline $\begin{array}{l}\text { Andreasen \& Andreasen } \\
(1988)^{44}\end{array}$ & $\begin{array}{c}4.9 \text { years } \\
(64 \text { days }-11.3 y)\end{array}$ & & $85 / 95$ & Root fractures & & $69(73)$ \\
\hline Yates $(1992)^{33}$ & 4.3 (0.5-7.7 years) & $12(9-20)$ & $21 / 22$ & Root fractures & & $20(95.2)$ \\
\hline Çaliskan \& Pehlivan (1996) & $2-6$ years & ago/40 & $48 / 56$ & Root fractures & & $42(75)$ \\
\hline Robertson et al. $(1996)^{46}$ & 15 years & $(7-19)$ & 198/488 & All & & $56(11)$ \\
\hline & & & & Crown fractures (106) & 0 & \\
\hline & & & & $\begin{array}{c}\text { Crown fractures + Luxation } \\
\text { (246) }\end{array}$ & 14 & \\
\hline Robertson et al. $(2000)^{47}$ & $2,3(0,2-17 y)$ & $10.4(5.3-61.3)$ & 455 & $\begin{array}{c}\text { Crown fractures }+ \text { pulpal } \\
\text { exposure (34) }\end{array}$ & 1 & $17(3,7)$ \\
\hline & & & & $\begin{array}{l}\text { Crown fractures + pulpal } \\
\text { exposure + Luxation (69) }\end{array}$ & 2 & \\
\hline Majorana et al. $(2002)^{48}$ & 6 months & $\mathrm{fev} / 55$ & $24 / 31$ & Root fractures & & $6(20)$ \\
\hline Feely et al. $(2003)^{49}$ & & ago/15 & $33 / 34$ & Root fractures & & $10(29.4)$ \\
\hline Lee et al. $(2003)^{50}$ & $3,6(1.2-7.9)$ & $10.6(7.1-17.8)$ & $35 / 55$ & Extrusions & & $19(35)$ \\
\hline Nikovi et al. $(2003)^{51}$ & $4(0.5-10.7)$ & $11.3(6.3-17.8)$ & $42 / 58$ & Lateral Luxations & & $23(40)$ \\
\hline Humphrey et al. $(2003)^{52}$ & 3,8 (65 days-9.3y) & $9.3(5.5-17.8)$ & $26 / 31$ & Intrusions & & $8(25.8)$ \\
\hline Wigen et al. $(2008)^{53}$ & $4(1-12)$ & $(6-17)$ & $39 / 51$ & Intrusions & & $18(35.3)$ \\
\hline Cvek et al. $(2008)^{54}$ & $6 m$ th- 12 years & $11.4(7-17)$ & $432 / 492$ & Root fractures & & $171(34.8)$ \\
\hline Hecova et al. $(2010)^{55}$ & 5 & & $423 / 889$ & All & & $80(9)$ \\
\hline $\begin{array}{l}\text { Wölner-Hanssen \& von Arx } \\
(2010)^{56}\end{array}$ & $2.3(1-7)$ & $25.5(9-48)$ & $29 / 32$ & Root fractures & & $2(6.2)$ \\
\hline Tsilingaridis et al. $(2012)^{57}$ & $4(2.2-10.8)$ & $9.4(6-16)$ & $48 / 60$ & Intrusions & & $16(33,3)$ \\
\hline Tsilingaridis et al. $(2016)^{5} 8$ & $4(1-12)$ & $9.6(5-18)$ & 230 & Intrusions & & $47(20,4)$ \\
\hline Abd Elmeguid et al. $(2015)^{4}$ & $3 \mathrm{mth}-13$ years & $06 /$ set & 228 & Avulsions & & $72(31.6)$ \\
\hline
\end{tabular}




\section{Clinical findings}

\section{Response to pulpal sensibility tests}

Although pulp sensibility testing still represents the most widely used diagnostic procedure for the assessment of pulp vitality, its worthiness after TDI is controversial. It is well known that the lack of response to pulp sensibility tests after TDI is a frequent finding during post-traumatic pulpal healing, and cannot be associated with later development of pulp necrosis. ${ }^{60}$ Moreover, clinical results showed that $60 \%$ of the teeth that developed PCO did not react to pulp testing at the time of injury. ${ }^{6}$ After obliteration, teeth tend to present a negative or lower response to sensibility tests, as can be seen in the data summarized in Table 2. ${ }^{6,18,25,27,46,50,51,61,62,63}$ Conversely, the extension of PCO affected sensibility, considering that teeth with partial PCO are significantly more responsive than totally obliterated teeth. Clinical reports also showed that the response to thermal and electrical pulp testing tends to decrease progressively in long-term follow-ups, as PCO becomes more pronounced. 17,20,63 Notwithstanding, clinical results could not evidence significant differences in the perception threshold between paired incisors with and without $\mathrm{PCO}$ after up to 5 years of follow-up. ${ }^{6}$

\section{Crown discoloration}

Crown discoloration to a yellowish hue is a common finding in teeth with PCO, and is caused by the excessive deposition of dentin, which may affect the light-transmitting properties of the tooth, resulting in a gradual opacity of the crown (Figure 4). Indeed, clinical studies reported highly frequent yellow discoloration, ranging from $8.3 \%{ }^{33}$ to $79 \% .{ }^{27}$ Gray discoloration (Figure 5) was a rare finding (1\%) in the

Table 2. Prevalence of crown discoloration and pulp necrosis in teeth with PCO after TDI: clinical reports.

\begin{tabular}{|c|c|c|c|c|c|c|}
\hline \multirow{2}{*}{ Author } & \multirow{2}{*}{$\begin{array}{c}\text { Follow-up } \\
\text { period - } \\
\text { Mean (range) }\end{array}$} & \multicolumn{2}{|c|}{ Sample features } & \multicolumn{2}{|c|}{ Clinical signs } & \multirow{2}{*}{$\begin{array}{c}\text { Radiographical } \\
\text { signs } \\
\text { Periradicular } \\
\text { status - N (\%) }\end{array}$} \\
\hline & & $\begin{array}{l}\text { Age at trauma - } \\
\text { Mean (range) }\end{array}$ & $\begin{array}{l}\text { Sample size - } \\
\text { patients/teeth }\end{array}$ & $\begin{array}{c}\text { Crown discoloration } \\
-\mathrm{N}(\%)\end{array}$ & $\begin{array}{l}\text { Response to electrical } \\
\text { pulp test - N (\%) }\end{array}$ & \\
\hline \multirow{3}{*}{$\begin{array}{l}\text { Holcomb \& Gregory } \\
(1967)^{18}\end{array}$} & \multirow{3}{*}{$4 y$} & \multirow{3}{*}{$11.2(7-16)$} & \multirow{3}{*}{$34 / 41$} & Absent 17 (42.5) & Negative 17 (42.5) & \multirow{3}{*}{$3(7.3)$} \\
\hline & & & & Mild 15 (37.5) & Positive 23 (57.5) & \\
\hline & & & & Severe 8 (20.0) & Uncertain 5 (12.5) & \\
\hline Andreasen $(1970)^{25}$ & 3.4 y $(1-12)$ & - & 108/189 & $9(21.4)$ & - & $3(7.1)$ \\
\hline \multirow{3}{*}{ Stalhane $(1971)^{61}$} & \multirow{3}{*}{$13-21$} & \multirow{3}{*}{$5 y$} & \multirow{3}{*}{76} & - & - & \multirow{3}{*}{$12(15.7)$} \\
\hline & & & & - & - & \\
\hline & & & & - & - & \\
\hline \multirow{3}{*}{$\begin{array}{l}\text { Jacobsen \& Kerekes } \\
(1977)^{27}\end{array}$} & \multirow{3}{*}{6 y (10-23) } & \multirow{3}{*}{9.8 y } & \multirow{3}{*}{122 teeth } & Yellow 90 (74.1) & Negative 47 (38.0) & Absent 101 (83.0) \\
\hline & & & & Yellow-brownish 6 (4.9) & Positive 62 (51.0) & Present 16 (13.0) \\
\hline & & & & Absent 26 (21.0) & Not tested 13 (1 1 1.0$)$ & Uncertain 5 (4.0) \\
\hline \multirow{3}{*}{$\begin{array}{l}\text { Andreasen et al. } \\
(1987)^{6}\end{array}$} & \multirow{3}{*}{5 у $(0.5-10)$} & & \multirow{3}{*}{96 teeth } & Yellow 8 (8.3) & Negative 58 (60.4) & \multirow{3}{*}{$1(1.0)$} \\
\hline & & & & Gray 1 (1.0) & Positive 18 (18.8) & \\
\hline & & & & Absent 87 (90.7) & Unknown 20(20.8) & \\
\hline \multirow{3}{*}{$\begin{array}{l}\text { Robertson et al. } \\
(1996)^{46}\end{array}$} & \multirow{3}{*}{16 y $(7-21)$} & \multirow{3}{*}{$(7-19)$} & \multirow{3}{*}{89 teeth } & Yellow 52 (69) & Negative 22 (27.0) & \multirow{3}{*}{$7(8.5)$} \\
\hline & & & & Gray 3 (1.0) & Positive (Normal) 42 (51.0) & \\
\hline & & & & Absent 25 (30.0) & Positive (Higher) 18 (22.0) & \\
\hline Feiglin $(1996)^{62}$ & 5 y (minimum) & - & 52 teeth & - & - & $2(3.8)$ \\
\hline Lee et al. $(2003)^{50}$ & - & - & 55 teeth & - & - & 0 \\
\hline Nikoui et al. $(2003)^{51}$ & $4 y$ & - & 23 teeth & - & - & $2(10.5)$ \\
\hline \multirow{3}{*}{$\begin{array}{l}\text { Oginni et al. } \\
(2009)^{63}\end{array}$} & & & & Yellow 186 (67.4) & Negative 82 (29.7) & \multirow{3}{*}{$75(27.2)$} \\
\hline & - & - & 276 teeth & Gray 34 (12.3) & $\begin{array}{c}\text { Positive (Normal) } 100 \\
(36.2)\end{array}$ & \\
\hline & & & & Absent 56 (20.3) & Positive (Higher) 94 (34.1) & \\
\hline
\end{tabular}


sample reported by Andreasen et al. ${ }^{6}$ and Robertsons. ${ }^{46}$ Only one study ${ }^{63}$ found a frequency of gray discoloration in $12.3 \%$ of the teeth with PCO. Table 2 illustrates clinical findings regarding the frequency of each hue of crown discoloration in teeth with PCO. The persistent gray discoloration can be attributed to the diffusion of breakdown products derived from pulpal hemorrhage and/or necrotic tissue decomposition into dentinal tubules. In the presence of infection, bacteria byproducts such as hydrogen sulfide may interact with iron from hemoglobin, forming iron sulfide, a black compound that further worsens discoloration. Clinical studies have reported that a greater number of teeth with gray discoloration developed periapical lesions and had a negative response to the electric pulp test. However, this difference was not statistically significant, and discoloration of the crown may persist without radiographical changes..$^{27,46,63}$ Nonetheless, even when not associated with pulp necrosis, a gray discoloration may pose a challenge to the clinician, and demand endodontic intervention to help restore aesthetics.

\section{Pulp necrosis after PCO}

The development of pulp necrosis is a late complication following PCO. Response to pulp sensibility tests and tooth discoloration are not reliable criteria to define pulp necrosis after PCO, because this diagnosis is based on radiographic signs of periapical changes. ${ }^{18,27,28}$ The etiology and pathogenesis of this complication have not been

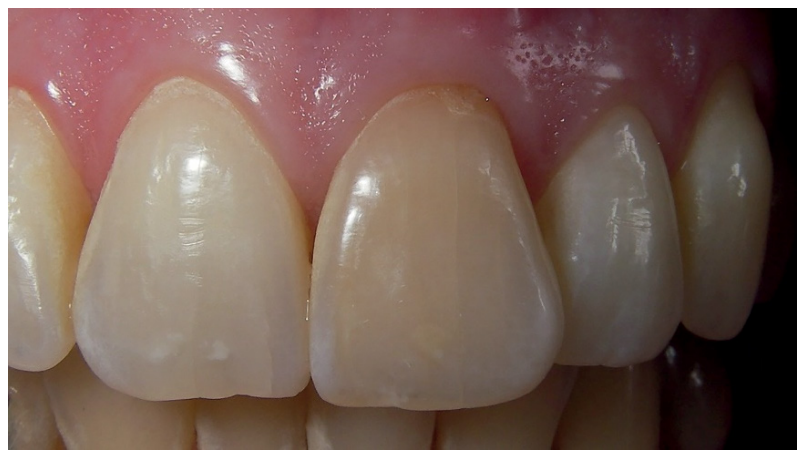

Figure 4. Crown discoloration to a yellowish hue in tooth 21. This is a common finding in teeth with PCO, and is caused by the excessive deposition of dentin, which may affect the light-transmitting properties of the tooth, resulting in a gradual opacity of the crown. TDI was classified as a concussion. established to date. The few studies with longterm observation of teeth with $\mathrm{PCO}^{27,46,61}$ reported frequency rates for apical periodontitis ranging from $1 \%^{6}$ to $27.5 \%{ }^{63}$ (Table 2 ). The severity of injury and the stage of root development at the moment of trauma were significantly associated with later development of necrosis after PCO. ${ }^{27}$ Furthermore, the extension and rate of root canal narrowing also appeared to be correlated with the development of periradicular radiolucency in teeth with $\mathrm{PCO},{ }^{17,27}$ Data summarized in Table 2 suggest that the frequency of pulp necrosis after PCO increases with longer follow-up periods. Therefore, additional factors, such as subsequent orthodontic treatment, new episodes of trauma, deep carious lesions and/or extensive restorative treatment have been speculated as predictors of the evolution to pulp necrosis after PCO, but there are no supportive studies to back these assumptions. ${ }^{45}$

The low frequency of pulp necrosis in teeth with $\mathrm{PCO}$ contraindicates prophylactic endodontic therapy, unlike its recommendation in previous studies. ${ }^{17,37}$ Only in those cases where signs or symptoms of apical periodontitis appear is there clear evidence for undertaking endodontic treatment. $3,5,18,27,28,32,41,45,60$ This recommendation is supported by clinical results showing success rates and favorable long-term prognosis of endodontically treated obliterated teeth, even though this may represent a real challenge. ${ }^{29,64}$ The currently available endodontic arsenal offers secure and practical tools for such an intervention. $.5,66,67,68,69$

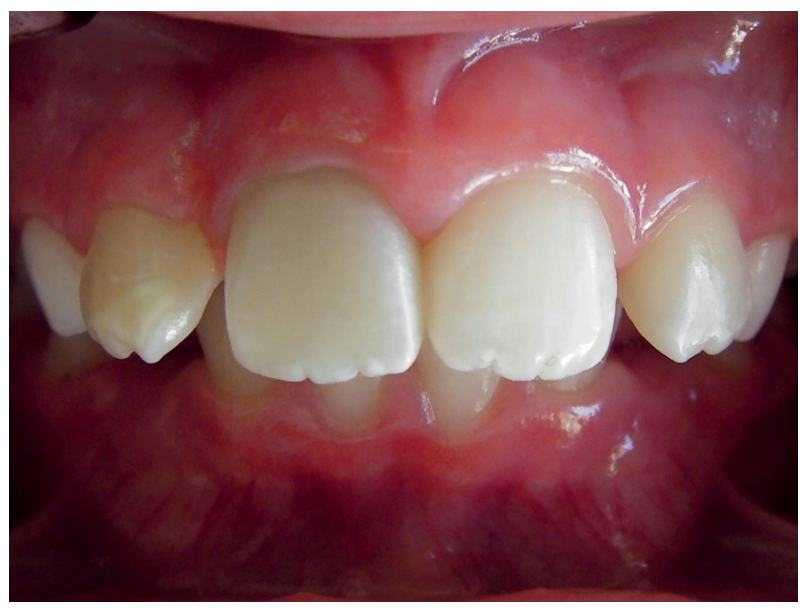

Figure 5. Gray discoloration of the crown of tooth 11 after subluxation. This is a rare finding in teeth with $\mathrm{PCO}$. 


\section{Conclusion}

Pulp canal obliteration is a frequent finding associated with pulpal revascularization after traumatic dental injuries that affect the pulpal neurovascular supply. It is a modality of pulpal healing after displacement of young permanent teeth with incomplete root development. Yellow discoloration of the crown due to excessive dentin apposition, and a lower or negative response to pulpal sensibility tests are common clinical manifestations. A late complication following PCO is the development of pulp necrosis, diagnosed by the presence of radiographic signs of periapical changes, because the response to

\section{References}

1. Nanci A. Ten Cate's Oral Histology. 8th ed. St. Louis: Mosby; 2012.

2. Andreasen FM, Andreasen JO, Cvek M. Root fractures. In: Andreasen JO, Andreasen FM, Andersson L, editors. Textbook and color atlas of traumatic injuries to the teeth. 4 th ed. Oxford: Blackwell; 2007. p. 337-71.

3. McCabe PS, Dummer PM. Pulp canal obliteration: an endodontic diagnosis and treatment challenge. Int Endod J. 2012 Feb;45(2):177-97. https://doi.org/10.1111/j.1365-2591.2011.01963.x

4. Abd-Elmeguid A, EISalhy M, Yu DC. Pulp canal obliteration after replantation of avulsed immature teeth: a systematic review. Dent Traumatol. 2015 Dec;31(6):437-41. https://doi.org/10.1111/edt.12199

5. Siddiqui SH, Mohamed AN. Calcific metamorphosis: a review. Int J Health Sci (Qassim). 2016 Jul;10(3):437-42.

6. Andreasen FM, Zhijie Y, Thomsen BL, Andersen PK. Occurrence of pulp canal obliteration after luxation injuries in the permanent dentition. Endod Dent Traumatol. 1987 Jun;3(3):103-15. https://doi.org/10.1111/j.1600-9657.1987.tb00611.x

7. Oksala E. Autotransplantation of vital maxillary canines: a clinical and radiographic study. Proc Finn Dent Soc.1974;70 (Suppl 1-3) 3-59.

8. Kallioniemi H, Oksala E. Significance of an open apex or fracture of the root tip for the prognosis of vital maxillary canine autotransplantation. Proc Finn Dent Soc. 1977 Jun;73(3):126-32.

9. Kristerson L. Autotransplantation of human premolars: a clinical and radiographic study of 100 teeth. Int J Oral Surg. 1985 Apr;14(2):200-13. https://doi.org/10.1016/S0300-9785(85)80093-4 pulp sensibility tests and tooth discoloration are not reliable. The pathogenesis of this complication is not yet clear, but its frequency was found to increase with longer follow-up periods, thus giving rise to speculations about the effect of later orthodontic treatment, new episodes of trauma and deep caries and/or extensive restorations. Considering that the frequency of pulp necrosis after PCO is rather low, there is no supportive evidence to indicate early prophylactic endodontic intervention in teeth with PCO. However, even when not associated with pulp necrosis, crown discoloration may pose a challenge to the clinician, and demand endodontic intervention to help restore aesthetics.
10. Andreasen JO, Paulsen HU, Yu Z, Bayer T, Schwartz O. A long-term study of 370 autotransplanted premolars. Part II. Tooth survival and pulp healing subsequent to transplantation. Eur J Orthod. 1990 Feb;12(1):14-24. https://doi.org/10.1093/ejo/12.1.14

11. Delivanis HP, Saver GJ. Incidence of canal calcification in the orthodontic patient. Am J Orthod. 1982 Jul;82(1):58-61. https://doi.org/10.1016/0002-9416(82)90547-4

12. Popp TW, Artun J, Linge L. Pulpal response to orthodontic tooth movement in adolescents: a radiographic study. Am J Orthod Dentofacial Orthop. 1992 Mar;101(3):228-33. https://doi.org/10.1016/0889-5406(92)70091-N

13. Roed-Petersen B, Andreasen JO. Prognosis of permanent teeth involved in jaw fractures. A clinical and radiographic follow-up study. Scand J Dent Res. 1970;78(4):343-52. https://doi.org/10.1111/i.1600-0722.1970.tb02081.x

14. Poswillo DE. Early pulp changes following reduction of open bite by segmental surgery. Int J Oral Surg. 1972;1 (2):87-97. https://doi.org/10.1016/S0300-9785(72)80023-1

15. Vedtofte P. Pulp canal obliteration after Le Fort I osteotomy. Endod Dent Traumatol. 1989 Dec;5(6):274-8. https://doi.org/10.1111/i.1600-9657.1989.tb00373.x

16. Glossary of endodontic terms. 8th ed. Chicago: American Association of Endodontics; 2012.

17. Patterson SS, Mitchell DF. Calcific metamorphosis of the dental pulp. Oral Surg Oral Med Oral Pathol. 1965;20(1):94101.https://doi.org/10.1016/0030-4220(65)90272-0

18. Holcomb JB, Gregory WB Jr. Calcific metamorphosis of the pulp: its incidence and treatment. Oral Surg Oral Med Oral Pathol. 1967 Dec;24(6):825-30. https://doi.org/10.1016/0030-4220(67)90521-X 
19. Smith JW. Calcific metamorphosis: a treatment dilemma. Oral Surg Oral Med Oral Pathol. 1982 Oct;54(4):441-4. https://doi.org/10.1016/0030-4220(82)90393-0

20. Schindler WG, Gullickson DC. Rationale for the management of calcific metamorphosis secondary to traumatic injuries. J Endod. 1988 Aug;14(8):408-12. https://doi.org/10.1016/S0099-2399(88)80126-2

21. West JD. The aesthetic and endodontic dilemmas of calcific metamorphosis. Pract Periodontics Aesthet Dent. 1997 Apr;9(3):289-93.

22. Amir FA, Gutmann JL, Witherspoon DE. Calcific metamorphosis: a challenge in endodontic diagnosis and treatment. Quintessence Int. 2001 Jun;32(6):447-55.

23. Gopikrishna V, Parameswaran A, Kandaswamy D. Criteria for management of calcific metamorphosis: review with a case report. Indian J Dent Res. 2004 Apr-Jun;15(2):54-7.

24. Malhotra N, Mala K. Calcific metamorphosis: literature review and clinical strategies. Dent Update. 2013 Jan-Feb;40(1):48-50. https://doi.org/10.12968/denu.2013.40.1.48

25. Andreasen JO. Luxation of permanent teeth due to trauma: a clinical and radiographic follow-up study of 189 injured teeth. Scand J Dent Res. 1970;78(3):273-86. https://doi.org/10.1111/j.1600-0722.1970.tb02074.x

26. Stålhane I, Hedegård B. Traumatized permanent teeth in children aged 7-15 years. Sven Tandlak Tidskr. 1975;68(5):157-69.

27. Jacobsen I, Kerekes K. Long-term prognosis of traumatized permanent anterior teeth showing calcifying processes in the pulp cavity. Scand J Dent Res. 1977 Nov;85(7):588-98. https://doi.org/10.1111/j.1600-0722.1977.tb02119.x

28. Lundberg M, Cvek M. A light microscopy study of pulps from traumatized permanent incisors with reduced pulpal lumen. Acta Odontol Scand. 1980;38(2):89-94. https://doi.org/10.3109/00016358009003483

29. Crek M, Granath L, Lundberg M. Failures and healing in endodontically treated non-vital anterior teeth with posttraumatically reduced pulpal lumen. Acta Odontol Scand. 1982;40(4):223-8. https://doi.org/10.3109/00016358209019816

30. Stroner WF, Van Cura JE. Pulpal dystrophic calcification. J Endod. 1984 May;10(5):202-4. Available from: http:// dx.doihttps://doi.org/10.1016/S0099-2399(84)80083-7

31. Birch R, Rock WP. The incidence of complications following root fracture in permanent anterior teeth. Br Dent J. 1986 Feb;160(4):119-22. https://doi.org/10.1038/sj.bdj.4805786

32. Torneck CD. The clinical significance and management of calcific pulp obliteration. Alpha Omegan. 1990;83(4):50-4.

33. Yates JA. Root fractures in permanent teeth: a clinical review. Int Endod J. 1992 May;25(3):150-7. https://doi.org/10.1111/j.1365-2591.1992.tb00778.x

34. Nielsen CJ, Bentley JP, Marshall FJ. Age-related changes in reducible crosslinks of human dental pulp collagen. Arch Oral Biol. 1983;28(8):759-64. https://doi.org/10.1016/0003-9969(83)90112-7
35. Biologydictionary.net Editors. Organ. 2014 [cited 2018 March 11]. Available from: https://biologydictionary.net

36. Andreasen FM. Pulpal healing after luxation injuries and root fracture in the permanent dentition. Endod Dent Traumatol. 1989 Jun;5(3):111-31. https://doi.org/10.1111/i.1600-9657.1989.tb00348.x

37. Rock WP, Grundy MC. The effect of luxation and subluxation upon the prognosis of traumatized incisor teeth. J Dent. 1981 Sep;9(3):224-30. https://doi.org/10.1016/0300-5712(81)90058-0

38. Avery J. Repair potential of the pulp. J Endod. 1981 May;7(5):205-12. https://doi.org/10.1016/S0099-2399(81)80177-X

39. Chiego DJ Jr, Avery JK, Klein RM. Neuroregulation of protein synthesis in odontoblasts of the first molar of the rat after wounding. Cell Tissue Res. 1987 Apr;248(1):119-23. https://doi.org/10.1007/BF01239971

40. Shuler SE, Howell BT, Green DB. Unusual pattern of pulp canal obliteration following luxation injury. J Endod. 1994 Sep;20(9):460-2. https://doi.org/10.1016/S0099-2399(06)80039-7

41. de Cleen M. Obliteration of pulp canal space after concussion and subluxation: endodontic considerations. Quintessence Int. 2002 Oct;33(9):661-9.

42. Jacobsen I, Zachrisson BU. Repair characteristics of root fractures in permanent anterior teeth. Scand J Dent Res. 1975 Nov;83(6):355-64. https://doi.org/10.1111/j.1600-0722.1975.tb00449.x

43. Oikarinen K, Gundlach KK, Pfeifer G. Late complications of luxation injuries to teeth. Endod Dent Traumatol. 1987 Dec;3(6):296-303. https://doi.org/10.1111/i.1600-9657.1987.tb00638.x

44. Andreasen FM, Andreasen JO. Resorption and mineralization processes following root fracture of permanent incisors. Endod Dent Traumatol. 1988 Oct;4(5):202-14. https://doi.org/10.1111/j.1600-9657.1988.tb00323.x

45. Calişkan MK, Pehlivan Y. Prognosis of rootfractured permanent incisors. Endod Dent Traumatol. 1996 Jun;12(3):129-36. https://doi.org/10.1111/j.1600-9657.1996.tb00111.x

46. Robertson A, Andreasen FM, Bergenholtz G, Andreasen JO, Norén JG. Incidence of pulp necrosis subsequent to pulp canal obliteration from trauma of permanent incisors. J Endod. 1996 Oct;22(10):557-60. https://doi.org/10.1016/S0099-2399(96)80018-5

47. Robertson A, Andreasen FM, Andreasen JO, Norén JG. Longterm prognosis of crown-fractured permanent incisors: the effect of stage of root development and associated luxation injury. Int J Paediatr Dent. Sep 2000 Sep;10(3):191-9. http:// dx.doi.org/10.1046/j.1365-263x.2000.00191.x

48. Majorana A, Pasini S, Bardellini E, Keller E. Clinical and epidemiological study of traumatic root fractures. Dent Traumatol. 2002 Apr;18(2):77-80. https://doi.org/10.1034/j.1600-9657.2002.180206.x 
- Pulp canal obliteration after traumatic injuries in permanent teeth-scientific fact or fiction?

49. Feely L, Mackie IC, Macfarlane T. An investigation of root-fractured permanent incisor teeth in children. Dent Traumatol. 2003 Feb;19(1):52-4. https://doi.org/10.1034/j.1600-9657.2003.00119.x

50. Lee R, Barrett EJ, Kenny DJ. Clinical outcomes for permanent incisor luxations in a pediatric population. II. Extrusions. Dent Traumatol. 2003 Oct;19(5):274-9. https://doi.org/10.1034/j.1600-9657.2003.00208.x

51. Nikoui M, Kenny DJ, Barrett EJ. Clinical outcomes for permanent incisor luxations in a pediatric population. III. Lateral luxations. Dent Traumatol. 2003 Oct;19(5):280-5. https://doi.org/10.1034/j.1600-9657.2003.00209.x

52. Humphrey JM, Kenny DJ, Barrett EJ. Clinical outcomes for permanent incisor luxations in a pediatric population. I. Intrusions. Dent Traumatol. 2003 Oct;19(5):266-73. https://doi.org/10.1034/j.1600-9657.2003.00207.x

53. Wigen TI, Agnalt R, Jacobsen I. Intrusive luxation of permanent incisors in Norwegians aged 6-17 years: a retrospective study of treatment and outcome. Dent Traumatol. 2008 Dec;24(6):612-8. https://doi.org/10.1111/j.1600-9657.2008.00686.x

54. Crek M, Tsilingaridis G, Andreasen JO. Survival of 534 incisors after intra-alveolar root fracture in patients aged 7-17 years. Dent Traumatol. 2008 Aug;24(4):379-87. https://doi.org/10.1111/i.1600-9657.2008.00701.x

55. Hecova H, Tzigkounakis V, Merglova V, Netolicky J. A retrospective study of 889 injured permanent teeth. Dent Traumatol. 2010 Dec;26(6):466-75. https://doi.org/10.1111/j.1600-9657.2010.00924.x

56. Wölner-Hanssen AB, Arx T. Permanent teeth with horizontal root fractures after dental trauma: a retrospective study. Schweiz Monatsschr Zahnmed. 2010;120(3):200-12.

57. Tsilingaridis G, Malmgren B, Andreasen JO, Malmgren $O$. Intrusive luxation of 60 permanent incisors: a retrospective study of treatment and outcome. Dent Traumatol. 2012 Dec;28(6):416-22. https://doi.org/10.1111/i.1600-9657.2011.01088.x

58. Tsilingaridis G, Malmgren B, Andreasen JO, Wigen TI, Maseng Aas AL, Malmgren O. Scandinavian multicenter study on the treatment of 168 patients with 230 intruded permanent teeth - a retrospective cohort study. Dent Traumatol. 2016 Oct;32(5):353-60. https://doi.org/10.1111/edt.12266
59. Andreasen JO. Traumatic injuries of the teeth. Copenhagen: Munksgaard; 1972.

60. Bastos JV, Goulart EM, Côrtes MIS. Pulpal response to sensibility tests after traumatic dental injuries in permanent teeth. Dent Traumatol. 2014 Jun;30(3):188-92. https://doi.org/10.1111/edt.12074

61. Stålhane I. [Permanent teeth with reduced pulp cavity following accidental injury: a clinical and radiographic study]. Sven Tandlak Tidskr. 1971 May;64(5):311-6. Swedish.

62. Feiglin B. Dental pulp response to traumatic injuries - a retrospective analysis with case reports. Endod Dent Traumatol. 1996 Feb;12(1):1-8. https://doi.org/10.1111/j.1600-9657.1996.tb00087.x

63. Oginni AO, Adekoya-Sofowora CA, Kolawole KA. Evaluation of radiographs, clinical signs and symptoms associated with pulp canal obliteration: an aid to treatment decision. Dent Traumatol. 2009 Dec;25(6):620-5. https://doi.org/10.1111/j.1600-9657.2009.00819.x 64.

64. Akerblom A, Hasselgren G. The prognosis for endodontic treatment of obliterated root canals. J Endod. 1988 Nov;14(11):565-7. https://doi.org/10.1016/S0099-2399(88)80092-X

65. van der Meer WJ, Vissink A, Ng YL, Gulabivala K. 3D Computer aided treatment planning in endodontics. J Dent. 2016 Feb;45:67-72. https://doi.org/10.1016/i.jdent.2015.11.007

66. Buchgreitz J, Buchgreitz M, Mortensen D, Biørndal L. Guided access cavity preparation using cone-beam computed tomography and optical surface scans - an ex vivo study. Int Endod J. 2016 Aug;49(8):790-5. https://doi.org/10.1111/iej.12516

67. Zehnder MS, Connert T, Weiger R, Krastl G, Kühl S. Guided endodontics: accuracy of a novel method for guided access cavity preparation and root canal location. Int Endod J. 2016 Oct;49(10):966-72.https://doi.org/10.1111/iej.12544

68. Toubes KM, Oliveira PA, Machado SN, Pelosi V, Nunes E, Silveira FF. Clinical approach to pulp canal obliteration: A case series. Iran Endod J. 2017;12(4):527-33. https://doi.org/10.22037/iej.v12i4.18006

69. Shah $P$, Chong BS. 3D imaging, 3D printing and $3 D$ virtual planning in endodontics. Clin Oral Investig. 2018 Mar;22(2):641-5 http://dx.doi.org/10.1007/s00784-018-2338-9 